\title{
INTRODUCTION
}

\section{URBAN PLANNING PARADIGMS: SHIFT OR PERSISTENCE?}

\author{
Kostyantyn MEZENTSEV, Oleksiy GNATIUK
}

\author{
DOI: https://doi.org/10.17721/2413-7154/2021.85.6-10
}

Collaborative planning theory has never achieved the paradigmatic status its advocates desired because of its internal diversity and limited scope; it seems inappropriate and unlikely for planning to coalesce around a single paradigm (Goodspeed, 2016). Planning theory is rather fragmented into a plurality of diverse 'paradigms' (Healey et al., 1982). Moreover, although there were marked differences between the traditional conception of town planning as an exercise in physical planning and design, and the conception of town planning as a rational process of decision-making directed at the analysis and control of urban systems, there was one thing that both these views had in common. Both presumed that the town planner was someone who possessed, or should possess, some specialist knowledge and skill - some substantive expertise - which the layperson did not possess (Taylor, 1999).

However, in the context of the neoliberal approach to urban development, principles and instruments of participatory urban planning have remarkably reshaped the set of interactions between actors of city development. The Central and East European post-socialist countries are not exclusion here. In particular, these changes are manifested through the expansion of initiators of urban projects, the introduction of new approaches and instruments, including those aimed at involving more stakeholders in the urban planning process, but also numerous conflicts due to disagreement with ineffective, inexpedient and injustice city-planning decisions. At least, it is possible to speak about 'a paradigm shift in public outreach programs': cities with successful public outreach programs include a variety of new technologies such as websites, online forums, visualization and participatory technologies (Kaylor, 2005), new technologies can help facilitate the production and distribution of information and are being increasingly used by government agencies to educate and communicate with their citizens (Manadarno et al., 2010).

The practice of implementing new approaches to urban planning and development in different local and national contexts raises a number of questions for theory and practice. Do traditional urban planning instruments remain effective in the new conditions, and should new instruments be relied upon in urban planning decisions? How to strike a balance between effective and participatory urban planning? Who should initiate urban development projects, and who should have the 'decisive word': private business, the public, activists? Is it possible (and how) to ensure consensus between the various participants in the urban planning process, and who in fact will benefit from the transition to the new paradigm? For short, do local planning paradigms shift or persist - why and how?

The aim of this themed issue lies in considering these questions from various perspectives and different angles of view, and in this manner to shed light on the nature of local and national trajectories of urban planning paradigms. To do this, the editorial team tried to collect theoretical and empirical researches, opinions, experiences and insights from the academia, practitioners, and civil society representatives with different professional and national background.

The special issue opens with an article by Anatolii Melnychuk, Olena Denysenko and Pavlo Ostapenko. The authors, intertwinning their academic and practical expertise, presents an analysis of the national institutional context of the urban development planning instruments in Ukraine in view of multidimensional transformations and adaptations in line with new trends of democratization, participation and collaboration. The influence of the main planning and participation instruments on the urban space transformation is revealed by virtue of two cases, Kryvyi Rih and Kherson, both representing second-order Ukrainian cities with different economic and political background. Via the in-depth interviews, the authors scrutinize the assessment of the key old and new planning and participation instruments by different stakeholders involved into the urban planning and development. The findings suggest the ambiguous nature of changing urban planning system in Ukraine with strong influence of local factors on the decision making process and participation of stakeholders. A clear trend towards democratization and increasing transparency of instruments and procedures, gradual rethinking of planning instruments and growing demand for them from both professionals and the public, and the emergence and improvement of new participation instruments occur simultaneously with the modest impact of new instruments on real transformation of urban space, discrediting planning instruments, institutions and urban policy, inadequate trust and cooperation between the stakeholders. In this light, the authors conclude, it is obvious that the urban planning system and its transformation grows out from the complex social process of post-socialist transition, where paradigm shifts in planning, reflecting the general trends of social development in recent decades, have overlapped the whole system of socioeconomic relations.

The following article by Carola Neugebauer addresses the current practices and fundamentals of urban renewal planning in Germany. In particular, she seeks to characterize the key stakeholders in urban renewal with regard to their concepts, practices, and opportunities in planning, to reveal the systemic and interdependencies between them with an emphasis on the formal and informal institutions, and to point on critical moments that deserve practical and scholarly debate and exploration, which are valuable not only for the German context but for the countries in (after) transition as well. The paper builds on research in three German cities - Bonn, Arnsberg, and Essen - all 
located in the West German Federal State of North Rhine-Westphalia, but representing different local political regimes and relationships between the city administrations and the public. Although Germany has far progressed towards a participatory, cooperative and balanced urban renewal planning (in particular, the citizens actively use the multiple opportunities to access urban planning processes, while the local authorities carefully implement the mandatory civic participation), the German participatory urban renewal planning also reveal ambivalent trends and new challenges. In particular, this is an overload of planners and a risk to the fairness and democratic legitimacy of renewal planning due the re-shuffling of political responsibility and accountability in planning, and the uncertainty about the un/intended effects participatory planning, in particular the contradictory role of urban activism, including such negative effects as the retardation of planning or even preventing important projects for the good of the many to be realized. Similar to Ukraine, the local stakeholder arrangements could be quite different depending on political regime in particular city, contrasting between conflictive, such as in Bonn, and the more collaborative and peaceful, such as in Essen and Arnsberg.

Daria Malchykova presents the author's vision of the planning decisions and urban activism prospects in the current transformation and renovation of urban space in Kherson, a city in the Southern Ukraine, in the mouth of Dnieper, focusing on the role of participatory budgeting and urban activism. In view of growing competition with the other cities in the areas of tourism, recreation and logistics, the city needs to overcome development challenges and gear the motion to more comfortable and attractive urban environment, in particular regeneration of brownfields and waterfront, restoration of the historical city centre and creation of new quality public spaces. These problems can be successfully solved only in the case of a dialogue between the city authorities and the city community delivering a true participatory management into the urban governance. However, the findings are not optimistic since only minor share of urban community is involved into the participatory budgeting, and the same refers to the total volume of the participatory budget. Moreover, the majority of the approved projects are solving small "backyard" problems rather than addressing the strategic agenda of urban development. Beyond the participatory budgeting, urban activism is quite sporadic and is driven by "small initiatives" of individual creative groups and entrepreneurs rather than by a top-down strategic plan promoted by the local authorities.

Mikalai Ulasiuk and Carola Neugebauer, balancing the insights, experiences and ideas of an involved practitioner and an external foreign scholar, focus on the current urban planning approaches in Brest, Belarus. This country, following its distinct political trajectory, has been broadly excluded from scholarly attention. Yet, that is why Belarusian experience of urban planning may be interesting for international audience. The authors argue that the urban planning in Brest follows a unique trajectory of gradual post-Soviet transformation that has been too little discussed by scholars and practitioners so far. In comparison with the other countries of the former Soviet Union, Belarus has retained a professional urban planning school and the centralized control over the whole chain of urban development; there have been only small steps to reform the institutions and processes of urban and regional planning. Although it has become mandatory to conduct a public discussion of urban planning documentation, the voices of citizens in urban planning are still soft. At the same time, the current Belarusian planning is substantially aligned with the modern planning approaches in the EU, namely in terms of leitmotifs (contents) and principles. The strong role of the power vertical is considered to be favourable and constraining at the same time. The question that is left open is whether these innovative ideas will trigger broader and incremental shifts within the Belarusian urban planning system.

The issues of participatory urban planning and urban transformation/regeneration are closely linked to the issue of urban conflictogenity. The stakeholders of urban development should have a sufficient level of mutual confidence to effectively use the participatory instruments of urban planning. Simultaneously, urban conflicts show hidden contradictions in society, reveal weaknesses, unmask the conflicting parties and thus may be instrumental in increasing awareness of stakeholders, including the public, in the formal and informal urban planning tools. The authoring team represented by Liudmyla Niemets, Olha Suptelo, Maryna Lohvynova and Kateryna Sehida demonstrates that a city of Kharkiv, being the second largest metropolis in Ukraine after Kyiv, is characterized by a high conflictogenity due to peculiarities of its historical, cultural and socio-economic development. The urban conflicts in the city are driven by a variety of factors, including centripetal migrations from peripheral areas to the city, forced migrations from the temporarily occupied territories of Ukraine, ethno-national and geopolitical divisions (Kharkiv is a geopolitical fault-line city), and last, but not the least, urban planning conflicts and conflicts related to the urban property. The concept of urban socio-geosystem is proposed for better conceptualization of urban conflicts and understanding their anatomy.

Whether or not the residents of cities in Ukraine are content with their comfort, inclusiveness and planning of residential developments? Putting this question, Olena Dronova, Karina Klyui and Diana Khomenko shift the discussion to the local level looking at a new residential complex "Liko-Grad" in Kyiv as an example of neoliberal approach in contemporary urban planning and governance. The survey of residents, as well as expert analysis of open-source data, evidence that neoliberal approach fosters the economic priorities and the accumulation of capital by individual coalitions of the private developers and the city administration. The individual districts are developed against the general vision of the city, and a specific urban space is often considered as a commodity that needs to be sold at the highest possible price in order to maximize short-term profit. At the same time, local people have little awareness about their importance and role in making management decisions regarding urban development. These neoliberal practices, in their distorted and hypertrophied form, are compared with the contrasting experience 
from some integrated urban development projects that are being implemented in Ukraine within the framework of international technical assistance and exchange programs. They provide opportunities for all segments of society to understand the consequences of decision-making in a particular area. The authors conclude that the path of Ukrainian cities to participatory democracy is just emerging.

To summarise, despite the overall transition to the more participative and inclusive urban planning, the specific trajectories of transition are highly depended on the local and national contexts. The diversity of national and local political regimes and institutions helps to understand the plurality of existing urban planning paradigms. Another lesson that must be learned is about the absence of a strict interdependence between the democracy and decentralization, on the one hand, and the effectiveness of participation instruments, on the other. The experiences from the more 'advanced' societies (as in Germany) could be promising; however, developed countries often face the same or similar problems like post-Soviet states that only feel way to the new planning paradigm. Simultaneously, in some contexts, the centralized and hierarchical old-fashioned urban planning system in Belarus may provide more real possibilities for public involvement into the decision making, and be more often to 'European' planning approaches compared with the decentralized Ukrainian system. In this respect, there are neither easy nor final receipts, suitable for all cultural and political contexts.

\section{ВСТУП}

\section{ПАРАДИГМИ МІСЬКОГО ПЛАНУВАННЯ: ЗМІНИ ЧИ СТАЛІСТЬ?}

\section{Костянтин МЕЗЕНЦЕВ, Олексій ГНАТЮК}

Теорія колаборативного планування ніколи не досягала парадигматичного статусу, якого бажали іï прихильники, через внутрішнє різноманіття та обмежений обсяг; об’єднання всієї різноманітності підходів до планування в рамках однієї парадигми видається недоречним та необгрунтованим (Goodspeed, 2016). Відповідно, теорію планування можна розглядати в рамках множини різноманітних «парадигм» (Неаley et al., 1982). Більше того, незважаючи на наявність істотних відмінності між традиційною концепцією міського планування як процесу матеріально-фізичного планування та проєктування та концепцією міського планування як раціонального процесу прийняття рішень, спрямованого на аналіз та контроль міських систем, обидва погляди мали спільну ознаку. А саме: фахівець з міського планування володіє або повинен володіти певними істотними спеціальними знаннями та вміннями, якими не володіє неспеціаліст (Taylor, 1999).

Проте, в контексті неоліберального підходу до розвитку міст, принципи та інструменти партисипативного міського планування істотно змінили форми та характер взаємодій між акторами міського розвитку. Не залишаються обабіч цього тренду і постсоціалістичні країни Європи. Розширення кола ініціаторів містобудівних проектів, впровадження нових підходів та інструментів, зокрема спрямованих на ширше залучення зацікавлених сторін до містобудівного процесу, але водночас і численні конфлікти через незгоду тієї чи іншої сторони з неефективними, недоцільними та несправедливими містопланувальними рішеннями. Принаймні, можна говорити про «зміну парадигми комунікації з громадськістю»: міста 3 успішними практиками публічної комунікації використовують безліч нових технологій, таких як веб-сайти, інтернетфоруми, візуалізації та технології участі (Kaylor, 2005); нові технології можуть сприяти виробництву та розповсюдженню інформації та все частіше використовується державними органами для навчання та спілкування зі своїми громадянами (Manadarno et al., 2010).

Практика реалізації нової містобудівної парадигми в різних локальних та національних контекстах ставить перед теорією та практикою низку питань. Чи залишаються в нових умовах ефективними традиційні інструменти міського планування, та чи варто покладатися на нові інструменти у прийнятті містопланувальних рішень? Як можливо досягти балансу між ефективністю та партисипативністю міського планування? Хто повинен ініціювати містобудівні проєкти, і за ким має бути «вирішальне слово»: приватний бізнес, адміністрація міста, активісти? Чи можливо (і яким чином) забезпечити консенсус між різними учасниками містобудівного процесу, і хто насправді виграє внаслідок переходу до нової парадигми? Якщо коротко: чи змінюються місцеві парадигми міського планування, і якщо так - то чому і яким чином?

Мета цього тематичного випуску полягає у розгляді цих питань з різних перспектив та точок зору та висвітленні таким чином характеру місцевих та національних траєкторій зміни парадигм міського планування. Для цього редакція журналу намагалася зібрати думки, ідеї та оцінки науковців, практиків міського планування та представників громадянського суспільства, що представляють різні країни та мають різний професійний досвід.

Спецвипуск відкривається статтею Анатолія Мельничука, Олени Денисенко та Павла Остапенка. Автори, що мають досвід академічної та практичної діяльності в галузі, представляють аналіз національного інституційного контексту інструментів планування міського розвитку в Україні 3 урахуванням багатовимірних перетворень та адаптацій у руслі нових трендів демократизації, партисипації та колаборації. Вплив основних інструментів планування та участі на трансформацію міського простору розкрито на прикладі двох кейсів - Кривого Рогу та Херсона - українських міст з різним економічним та політичним 
підгрунтям. Використавши глибинні інтерв’ю як метод дослідження, автори здійснили аналіз поглядів різних акторів, залучених до містобудівної діяльності, на ключові «старі» та «нові» інструменти планування та участі. Результати свідчать про суперечливий характер зміни системи міського планування в Україні та сильний вплив місцевого контексту на процес прийняття рішень та участь зацікавлених сторін. 3 однієї сторони, спостерігається чітка тенденція до демократизації та підвищення прозорості інструментів та процедур, поступове переосмислення інструментів планування та зростаючий попит на них як 3 боку фахівців, так і громадськості, а також поява та вдосконалення нових інструментів участі. Водночас, очевидними $є$ неістотний вплив нових інструментів на реальні процеси перетворення міського простору, дискредитацію не лише інструментів планування, але й інституцій та міської політики в цілому, низький рівень довіри та співпраці між стейкголдерами. У світлі цих фактів, на думку авторів, можна стверджувати, що у транзитних країнах система планування міського простору та процеси його перетворення є результатом складних суспільних процесів, де парадигмальні зрушення у сфері планування, які відображають загальні тренди суспільного розвитку останніх десятиліть, наклалися на процеси перебудови всієї системи соціально-економічних відносин.

Каролою Нойгебауер розглянуто сучасні практики та засади планування реновації міст у Німеччині. Зокрема, дано характеристику ключових акторів, залучених до реновації міст, з урахуванням їхніх засадничих принципів, практик та можливостей у процесі міського планування, розкрито систему взаємозалежностей між офіційними та неформальними інституціями, а також вказано на проблемні аспекти, що заслуговують на подальше дослідження й обговорення та можуть бути цінними не лише для розуміння німецького контексту міського планування, але й для (пост)транзитних країн. Емпіричну базу для дослідження сформовано матеріалом трьох німецьких міст - Бонна, Арнсберга та Ессена. Усі вони розташовані у західнонімецькій федеральній землі Північний Рейн-Вестфалія, але представляють різні місцеві політичні режими та моделі взаємодії між міськими адміністраціями та громадськістю. Незважаючи на те, що Німеччина досить далеко просунулась на шляху до учасницького, колаборативного та збалансованого міського планування (зокрема, звичайні громадяни активно використовують різноманітні інструменти участі в процесі планування, тоді як місцева влада ретельно дотримується принципів громадського залучення), планування міського оновлення в Німеччині також має певні неоднозначні тенденції та нові виклики. Зокрема, це перевантаження фахівцівпланувальників та ризик для справедливості та демократичної легітимності реноваційного планування через перекладання політичної відповідальності та підзвітності, а також неоднозначна оцінка не/передбачуваних наслідків партисипативного планування, зокрема суперечлива роль громадського активізму, включаючи такі негативні наслідки, як затримка чи навіть повна зупинка реалізації важливих проєктів для блага всього міста. Подібно до України, взаємодія місцевих стейкголдерів та конфігурація їх альянсів може істотно відрізнятись в залежності від особливостей політичного режиму в конкретному місті. Наприклад, висока конфліктогенність міського планування в Бонні контрастує на тлі колаборативного та злагодженого містобудівного процесу в Ессені та Арнсберзі.

Дар'я Мальчикова презентує авторське бачення планувальних рішень та перспектив міського активізму в рамках поточної трансформації та оновлення міського простору в Херсоні, місті на півдні України, зосереджуючи увагу на ролі бюджету участі та міського активізму. 3 огляду на зростаючу конкуренцію 3 іншими містами у сферах туризму, відпочинку та логістики, місто стоїть перед необхідністю подолати виклики свого розвитку та рухатись в напрямку до формування більш комфортного та привабливого міського середовища, зокрема регенерацію браунфілдів та набережної Дніпра, реставрацію історичного центру міста та створення нових якісних публічних просторів. Ці проблеми можна успішно вирішити лише у випадку діалогу між міською владою та міською громадою, забезпечуючи справжнє залучення громади до міського управління. Однак результати не є надто оптимістичними, оскільки лише незначний прошарок містян бере участь у формуванні бюджету участі, а загальний обсяг бюджету участі дуже малий. Більше того, більшість затверджених проєктів спрямовані на задоволення суто локальних, тактичних інтересів мешканців та не орієнтовані на вирішення стратегічних цілей розвитку міста. Окрім практики бюджету участі, міський громадський активізм в Херсоні є досить епізодичним та забезпечується «маленькими ініціативами» окремих творчих груп та підприємців, а не стратегічною політикою міської влади.

Мікалай Уласюк, архітектор-практик, та Карола Нойгебауер, університетський вчений, синтезуючи теоретичні ідеї та практичний досвід, представляють аналіз сучасних підходів до міського планування в місті Брест, Білорусь. Ця країна, слідуючи специфічним суспільно-політичним шляхом, не часто стає об’єктом уваги науковців, проте саме тому білоруський досвід міського планування може бути особливо цікавим для міжнародної аудиторії. Автори стверджують, що містобудівне планування у Бресті слідує унікальною траєкторією поступової пострадянської трансформації, яка до цього часу недостатньо обговорювалася вченими та практиками. У порівнянні з іншими країнами колишнього Радянського Союзу, в Білорусі добре збережено професійну школу міського планування та централізований контроль над усім ланцюгом містобудівної діяльності; були зроблені лише невеликі кроки для реформування інститутів та процесів міського та регіонального планування. Хоча проведення публічного обговорення містобудівної документації стало обов'язковим, голоси громадян як учасників містобудівного процесу все ще звучать тихо на фоні інших залучених акторів, таких як держава та запрошені нею інвестори. Водночас, спостерігається істотне узгодження сучасних тенденцій в міському плануванні в Білорусі з сучасними підходами до 
планування в СС, а саме з точки зору лейтмотивів (змісту) та принципів. Сильна владна вертикаль відіграє для цього як сприятливу, так і водночас стримуючу роль. Питання, яке залишається відкритим, полягає в тому, чи спричинять ці інноваційні ідеї більш широкі та системні зміни в білоруській системі міського планування.

Питання міського планування та трансформації/регенерації міст тісно пов’язані $з$ проблемою міської конфліктогенності. Актори, що беруть участь в плануванні розвитку міста, повинні мати достатній рівень взаємної довіри для ефективного використання інструментів участі. Водночас, міські конфлікти демонструють приховані суперечності в суспільстві, виявляють його слабкі місця та конфліктуючі сторони, тому можуть сприяти зростанню обізнаності стейкголдерів, включаючи громадськість, щодо формальних та неформальних інструментів міського планування та участі. Авторський колектив у складі Людмили Нємець, Ольги Суптело, Марини Логвинової та Катерини Сегіди наводять аргументи на користь високої конфліктогенності міста Харкова, другого за величиною метрополісу в Україні після Києва, що обумовлена особливостями його історичного розвитку, а також сучасною соціально-економічною та етнокультурною ситуацією. Міські конфлікти в Харкові зумовлені широким спектром різних факторів, включаючи доцентрові міграції з периферійних територій до міста, вимушені міграції з тимчасово окупованих територій України, етнонаціональні та геополітичні поділи (Харків як геополітично розділене місто). Не останню роль відіграють також містобудівні конфлікти та конфлікти, пов'язані з питаннями міською власністю. Автори пропонують використання концепції міської соціогеосистеми для кращого осмислення міських конфліктів та розуміння їх анатомії.

Чи задоволені жителі міст України комфортом, інклюзивністю та плануванням житлової забудови? Поставивши це питання, Олена Дронова, Каріна Клюй та Діана Хоменко переносять дискусію на локальний рівень, розглядаючи новий житловий комплекс «Ліко-Град» у Києві як приклад реалізації неоліберального підходу в сучасному міському плануванні та управлінні. Опитування мешканців, а також експертний аналіз відкритих даних свідчать про те, що неоліберальний підхід сприяє реалізації економічних пріоритетів та накопиченню капіталу окремими коаліціями приватних забудовників та міської адміністрації. Окремі райони розвиваються всупереч загальному баченню розвитку міста, а конкретний міський простір часто розглядається як товар, який потрібно продати за максимально можливою ціною, щоб максимізувати короткостроковий прибуток. Водночас місцеве населення слабко усвідомлює свою важливість та роль у прийнятті управлінських рішень щодо міського розвитку. Ці неоліберальні практики у своїй спотвореній та гіпертрофованій формі порівнюються з контрастним досвідом деяких інтегрованих проєктів міського розвитку, що реалізуються в Україні в рамках програм міжнародної технічної допомоги та обміну та дають можливість усім верствам суспільства зрозуміти наслідки прийняття планувальних рішень стосовно конкретної території. Автори приходять до висновку, що шлях українських міст до демократії участі лише перебуває на шляху свого становлення.

Підводячи підсумки: незважаючи на загальний рух до більш інклюзивного та партисипативного міського планування, конкретні траєкторії переходу сильно залежать від місцевого та національного контексту. Аналіз ролі різноманітності національних та місцевих політичних режимів та інституцій допомагає зрозуміти множинність існуючих парадигм містобудування. Ще один урок, який слід засвоїти - відсутність суворої взаємозалежності між рівнем демократії та децентралізації, 3 одного боку, та ефективністю інструментів участі, 3 іншого. Досвід більш «передових» суспільств (як у Німеччині) може бути надзвичайно корисним; однак розвинені країни часто зіштовхуються 3 тими ж або подібними проблемами, як і пострадянські суспільства, які лише «намацують» шлях до нової парадигми планування. Водночас, в деяких контекстах, централізована, ієрархічна та консервативна система міського планування в Білорусі може надавати більше реальних можливостей для залучення громадськості до процесу прийняття рішень і краще імплементувати «європейські» підходів до планування порівняно 3 децентралізованою українською системою. У цьому відношенні немає ні легких, ні остаточних рішень, придатних для будь-якого культурного чи політичного контексту.

\section{References:}

Goodspeed, R. (2016). The death and life of collaborative planning theory. Urban Planning, 1(4), 1-5. doi: 10.17645/up.v1i4.715.

Healey, P., McDougall, G., \& Thomas, M. (eds). (1982). Planning Theory: Prospects for the 1980s. Oxford: Pergamon.

Kaylor, C. (2005). The State of Local E-Government and E-Democracy: Benchmarking the Progress of U.S. Cities at Providing Online Opportunities for Citizen Engagement. Columbus, OH: Institute for Public Service and Public Policy.

Mandarano, L., Meenar, M., \& Steins, C. (2010). Building social capital in the digital age of civic engagement. Planning Literature, 25, 123-135. doi: 10.1177/0885412210394102.

Taylor, N. (1999). Anglo-American town planning theory since 1945: three significant developments but no paradigm shifts. Planning Perspectives, 14(4), 327-345. doi: 10.1080/026654399364166. 